\title{
Burnout Among General Surgeons in Turkey
}

\section{Türkiye'deki Genel Cerrahlar Arasında Tükenmişlik}

\author{
(1) Emrah Yeşilbağ19 (1) İbrahim Ethem Cakcak², (1) Tamer Sağıroğlu³ \\ 1 Ünye Government Hospital, Clinic of General Surgery, Ordu, Turkey \\ ${ }^{2}$ Trakya University Faculty of Medicine, Department of General Surgery, Edirne, Turkey \\ ${ }^{3}$ Namık Kemal University Faculty of Medicine, Department of General Surgery, Tekirdağ, Turkey
}

\section{HIIIIII ABSTRACT}

Aim: Burnout is a syndrome that is very common among surgeons. It is defined by emotional exhaustion (EE), depersonalization (DP), and decreased personal success. This study aimed to investigate burnout in general surgeons in Turkey and to determine the risk factors for burnout.

Method: Of the total of 4,395 general surgeons in Turkey, 630 were included in this study. Each participant was asked to complete the Sociodemographic Data Form, Maslach Burnout Inventory, and Minnesota Satisfaction Questionnaire (MSQ) either by face-to-face interview or via electronic questionnaire.

Results: Of the 630 participants included in this study, 53 (8.4\%) and 577 (91.6\%) was female and male, respectively. The highest participation rate was from the Marmara region (36\%), while the lowest participation rate was from the Eastern Anatolia region (3.13\%). Attending physicians comprised the largest number of participants (72\%). Those who perceived themselves as successful, with more work experience and higher academic titles, had decreased EE, personal accomplishment, and DP as well as increased general, external, and internal satisfaction.

Conclusion: We observed that most of the general surgeons in Turkey experienced burnout syndrome. To address this, we suggest that health systems and working conditions in Turkey should be reviewed and that the working standards and rights of the healthcare workers should be revised.

Keywords: General surgery, burnout, Maslach Burnout Inventory, Minnesota Satisfaction Questionnaire, Turkey

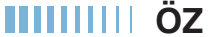

Amaç: Tükenmişlik, cerrahlar arasında çok yaygın olan ve duygusal tükenme, duyarsızlaşma ve azalmış kişisel başarı ile tanımlanan bir sendromdur. Bu çalışmanın amacı Türkiye'deki genel cerrahlarda tükenmişliği araştırmak ve tükenmişlik için risk faktörlerini belirlemektir.

Yöntem: Türkiye'deki 4.395 genel cerrahtan 630'u bu çalışmaya dahil edildi. Her bir katılımcıdan yüz yüze görüşme veya e-anket yoluyla "Sosyodemografik Veri Formu", "Maslach Tükenmişlik Envanteri" ve "Minnesota Memnuniyet Anketini" (MSQ) doldurmaları istenmiştir.

Bulgular: Altı yüz otuz katılımcının 53’ü kadın $(\% 8,4)$ ve 577’si $(\% 91,6)$ erkekti. En yüksek katılım oranı Marmara bölgesinden (\%36), en düşük katılım oranı Doğu Anadolu bölgesinden $(\% 3,13)$ oldu. Katılımcıların çoğu uzman hekimdi $(\% 72)$. Kendini daha başarılı görenlerde, daha fazla iş tecrübesi olanlarda ve daha yüksek akademik unvanlara sahip olanlarda duygusal tükenme, kişisel başarı ve duyarsızlaşma daha azdı ve genel, dış ve iç tatmin artmıştı.

Sonuç: Türkiye'deki genel cerrahların çoğunun tükenmişlik sendromu yaşadığını gördük. Bu nedenle sağlık sisteminin ve çalışma koşullarının gözden geçirilmesi, sağlık çalışanlarının çalışma standartlarının ve haklarının iyileştirilmesi gerektiğine inanıyoruz.

Anahtar Kelimeler: Genel cerrahi, tükenmişlik, Maslach Tükenmişlik Envanteri, Minnesota Memnuniyet Anketi, Türkiye

\section{Introduction}

Burnout syndrome was first described in the 1960s and 1970s in volunteer staff working with drug addicts in city clinics, probation officers, lawyers serving vulnerable populations, and healthcare workers., ${ }^{1,2}$ Burnout syndrome is different from work stress and depression, which are often confused in society. In burnout syndrome, individuals believe they are not given proper financial and emotional compensation for the energy they input at work, which leads to their loss of interest and enthusiasm for work. As a result, burnout 
syndrome impairs the balance between individuals' work and their feeling of being satisfied with their job. Maslach and Pines ${ }^{2}$ described the following three key dimensions of burnout: Overwhelming emotional exhaustion (EE), feelings of cynicism and detachment from the job [depersonalization (DP), and a sense of ineffectiveness and lack of personal accomplishment (PA)]. ${ }^{1,3}$ Sub-concepts, such as EE, DP, and diminished personal skills, and accomplishments related to burnout syndrome are useful to understand the topic. EE is manifested by lack of energy and feeling that one's emotional resources have been exhausted. ${ }^{3,4} \mathrm{~A}$ decrease in an individual's emotions of competence can cause a decrease in such individual's skills and accomplishments. The following two common signs of burnout were described by Balch and Shanafelt ${ }^{5}$ for healthcare professionals: 1) treating patients and colleagues as objects rather than humans and 2) feeling emotionally exhausted.

The causes of burnout syndrome can be grouped into two main categories: environmental or individual. Environmental causes can include one's working environment, working hours, working conditions, insufficient wages, administrative pressure, a feeling of not being appreciated, inadequate training, and insufficient tools, among others. ${ }^{6,7}$ Individual reasons include number of children, age, marriage, individual expectations, selfesteem, experience, and excessive attachment to work, among others. ${ }^{6,8}$ People with similar working conditions may be subject to burnout or may be unaffected due to different individual characteristics. ${ }^{9}$ Physical symptoms of burnout syndrome include fatigue, sensitivity to diseases, sleep disorders, headaches, and weight loss. Emotional and mental symptoms include depressive affect, skepticism, vulnerability, addiction problems, family conflicts, social isolation, feeling of failure, forgetfulness, and difficulty in focusing.

Burnout syndrome is more common in people with occupations that require face-to-face contact, such as physicians, nurses, physiotherapists, teachers, and social workers. ${ }^{3}$ It is difficult to provide the exact figures regarding the prevalence of burnout, since it is related to many individual, environmental, and managerial factors. However, it has been suggested that burnout affects the performance of $30 \%$ to $40 \%$ of physicians. ${ }^{10}$ However, it has been reported that more than $50 \%$ of practicing surgeons and approximately $70 \%$ of general surgery residents have symptoms of burnout. ${ }^{11,12}$ The Maslach Burnout Inventory (MBI) is commonly used to assess burnout in healthcare workers. ${ }^{13}$ In this study, the Sociodemographic Data Form, MBI, and Minnesota Satisfaction Questionnaire (MSQ) were used to identify burnout. This study aimed to determine the levels of burnout and job satisfaction in general surgeons in Turkey and to use these data to develop solutions.

\section{Materials and Methods}

All types of general surgeons in Turkey were represented in this cross-sectional descriptive study (i.e., those from university hospitals, education and research hospitals, state hospitals, and private health institutions). The research cohort comprised a total of 4,395 physicians working in general surgery in Turkey. Based on a 95\% confidence interval, a 0.5 error level, and MBI average score, the number of participants that should be represented in this study was 627. This study utilized a simple random sampling method for its sample selection. This study included a total of 630 general surgeons who are currently working in Turkey. A total of 630 questionnaires were used in the study, of which 495 were conducted as face-to-face interviews, while the other 135 were electronic questionnaires. Data regarding the sociodemographic characteristics and occupational status of the participants were recorded and evaluated.

\section{Maslach Burnout Inventory (MBI)}

The MBI was developed by Maslach and Jackson ${ }^{6}$ and it consists of 22 items on three subscales. The Turkish adaptation of the MBI was performed by Ergin. ${ }^{14}$ The first subscale is the MBI EE subscale, which defines the feeling of excessive wear and tiredness of employees who are exhausted and overburdened by their profession. The second subscale is the DP (MBI DP) subscale, which defines the attitude of employees toward the people they meet, showing DP indicating a negative and cynical attitude that is devoid of emotion, without considering the uniqueness of each of the individuals. The third subscale is the PA (MBI PA) subscale, which defines the state in which individuals feels competent and successful in their job. The MBI EE and MBI DP subscales were scored as never " 0 " and always "4," whereas the MBI PA subscale was scored as never " 4 ," and always " 0 " in order to obtain standard values. The three subscale scores were assessed independently of each other and the burnout level was determined by taking the average of all three scores. The level of burnout was considered to be directly proportional to the amount of points obtained on the MBI subscales.

\section{Minnesota Satisfaction Questionnaire (MSQ)}

MSQ, which measures the job satisfaction of employees, is a five-point likert-scale that consists of three subscales. The internal, external, and general satisfaction levels were determined with the 20 items used in the MSQ. For each subscale, "5" was the highest score and "1" was the lowest score. The total evaluation was done by taking the average of the three subscale scores. The first subscale is the Intrinsic Satisfaction (MSQ IS) subscale, which includes satisfaction elements related to the job, such as success, recognition, being appreciated, taking more responsibility 
related to one's job, self-development, and being promoted. There are 12 questions in this subscale. Therefore, the sum of the score obtained is divided by 12 to obtain the IS score. The second subscale is the Extrinsic Satisfaction (MSQ ES) subscale, which includes elements of the working environment, such as business policy and management, type of supervision, director, working conditions, salary, and relations with subordinates. There are 8 questions in this subscale. Therefore, the sum of the score obtained is divided by 8 to determine the ES score. The third subscale is the general satisfaction (MSQ GS) subscale, which includes all 20 questions from the scale.

\section{Statistical Analysis}

Statistical analysis was done using the Statistical Package for Social Sciences for Windows, version 22.0 (IBM Corp., Armonk, NY, USA). Conformity of the data to normal distribution was determined by Kolmogorov-Smirnov and Shapiro-Wilk tests. Continuous variables were expressed as mean \pm standard deviation (mean $\pm \mathrm{SD}$ ), while categorical variables were expressed as frequency (n) and percentage (\%). Mann-Whitney U, Kruskal-Wallis, and Spearman Correlation tests were used to compare the scores of the scales used in this study. $\mathrm{P}$ values less than 0.05 were considered statistically significant.

\section{Results}

The 630 general surgeons who participated in this study were categorized according to the following criteria: gender, age, district, institution, academic title, work experience, material and emotional satisfaction, DP, intellectual and emotional burnout, negative criticism of work, choosing to work in general surgery again if given the chance, finding themselves successful in the profession, and departure from the work without meeting retirement criteria.

Demographic characteristics of the general surgeons participating in this study are shown in Table 1. Fiftythree of the participants were female (8.4\%) and 577 were male $(91.6 \%)$. The highest participation rate was from the Marmara region (36\%), while the lowest participation rate was from the Eastern Anatolia region (5.1\%). Attending physicians had the highest participation rate (72.4\%).

Of the total participants included in this study, $70.8 \%$ were not materially satisfied, while $74.4 \%$ were emotionally satisfied. The scores of those who were emotionally dissatisfied had statistically higher MBI scores and statistically lower MSQ scores $(\mathrm{p}<0.05)$. This indicates that these participants had more EE, DP, decrease in PA levels, and less IS, ES, and GS (Table 2).

Based on MBI, the DP score was statistically lower for female participants $(\mathrm{p}=0.047)$. This result indicates that the rate of DP among women is lower compared to the DP among men (Table 3). When determining which participants saw themselves as successful and those that did not, the scores of those that said "No, I don't" $(n=60)$ were significantly higher on MBI and significantly lower on MSQ $(\mathrm{p}<0.05)$

Table 1. Demographic characteristics of the general surgeons

\begin{tabular}{|c|c|c|}
\hline Variables & (n) & $(\%)$ \\
\hline \multicolumn{3}{|l|}{ Location } \\
\hline Marmara & 227 & 36.0 \\
\hline Aegean & 81 & 12.9 \\
\hline Mediterranean & 65 & 10.3 \\
\hline Southeastern Anatolia & 51 & 8.1 \\
\hline Eastern Anatolia & 32 & 5.1 \\
\hline Black Sea & 59 & 9.4 \\
\hline Central Anatolia & 115 & 18.3 \\
\hline \multicolumn{3}{|l|}{ Gender } \\
\hline Female & 53 & 8.4 \\
\hline Male & 577 & 91.6 \\
\hline \multicolumn{3}{|l|}{ Age } \\
\hline $30-40$ & 303 & 48.1 \\
\hline $41-50$ & 219 & 34.8 \\
\hline $51-60$ & 93 & 14.8 \\
\hline$\geq 61$ & 15 & 2.4 \\
\hline \multicolumn{3}{|l|}{ Employment institute } \\
\hline University hospital & 148 & 23.5 \\
\hline Education research hospital & 161 & 25.6 \\
\hline State hospital & 213 & 33.8 \\
\hline Private hospital & 108 & 17.1 \\
\hline \multicolumn{3}{|l|}{ Academic degree } \\
\hline Professor & 67 & 10.6 \\
\hline Associate professor & 66 & 10.5 \\
\hline Assistant professor & 41 & 6.5 \\
\hline Attending physician & 456 & 72.4 \\
\hline \multicolumn{3}{|l|}{ Work experience (years) } \\
\hline $6-10$ & 192 & 30.5 \\
\hline $11-15$ & 165 & 26.2 \\
\hline $16-20$ & 97 & 15.4 \\
\hline $21-25$ & 84 & 13.3 \\
\hline$\geq 26$ & 92 & 14.6 \\
\hline \multicolumn{3}{|l|}{ Emotionally satisfied } \\
\hline Yes & 469 & 74.4 \\
\hline No & 161 & 25.6 \\
\hline \multicolumn{3}{|l|}{ Satisfied with salary } \\
\hline Yes & 184 & 29.2 \\
\hline No & 446 & 70.8 \\
\hline \multicolumn{3}{|l|}{ I'm successful } \\
\hline Yes & 570 & 90.5 \\
\hline No & 60 & 9.5 \\
\hline
\end{tabular}


compared to the scores of participants who said "Yes, I do" $(n=570)$. This result indicates that EE, DP, and decrease in PA were higher and that IS, ES, and GS were lower in the group that said "No, I don't" (Table 3).

In response to the question "If you can go back to the past, would you choose general surgery again?," 368 (58.4\%) participants said "Yes, I would" and 262 (41.6\%) said "No, I would not" (Table 4). When the relationship between the answer to this question and the burnout sub-dimensions was examined, the levels of burnout in the EE, DP, and PA sub-dimensions of the MBI were significantly higher among the physicians who said "No" $(\mathrm{p}<0.001)$.

When evaluating the thought of departing from the work without retirement, the MBI scores of the participants who said "Yes, I would" (191 participants) were significantly higher, while the MSQ scores were significantly lower compared to the participants who said "No, I would not" (439 participants) (Table 4).
The participants were grouped according to their titles and group scores were calculated statistically (Table 5). EE and DP were lower, while GS and ES were higher in group 1 (professor) compared to group 2 (associate professor) and group 3 (assistant professor). Further, EE, DP, and decrease in PA were lower and GS, IS, and ES were higher in group 1 compared to group 4 (attending physicians). In addition, GS, IS, and ES were higher in group 2 compared to group 4. EE was lower in group 3 compared to group 4. These findings were statistically significant $(\mathrm{p}<0.05)$

When evaluating the ages (Table 6) and work experience (Table 7) of the participants, it was found that the MBI scores decreased, while the MSQ scores increased as the age and work experience increased. This result indicates that burnout, DP, and decrease in PA is lower and that GS, ES, and IS is higher in individuals who are older and have more work experience.

Table 2. Minnesota Satisfaction Questionnaire and Maslach Burnout Inventory values according to emotional satisfaction and salary satisfaction

\begin{tabular}{|c|c|c|c|c|c|c|}
\hline & \multicolumn{3}{|c|}{ Emotionally satisfied } & \multicolumn{3}{|c|}{ Satisfied with salary } \\
\hline & Yes $(n=469)$ & No $(n=161)$ & $\mathrm{p}$ & Yes $(n=184)$ & No $(n=446)$ & $\mathrm{p}$ \\
\hline MBI EE & $1.60 \pm 0.77$ & $2.45 \pm 0.68$ & $0.001 *$ & $1.40 \pm 0.84$ & $1.98 \pm 0.77$ & $0.001 *$ \\
\hline MBI D & $1.16 \pm 0.80$ & $1.82 \pm 0.81$ & $0.001^{*}$ & $1.07 \pm 0.84$ & $1.43 \pm 0.83$ & $0.001 *$ \\
\hline MBI PA & $1.03 \pm 0.66$ & $1.51 \pm 0.82$ & $0.001^{*}$ & $0.94 \pm 0.74$ & $1.24 \pm 0.71$ & $0.001 *$ \\
\hline MSQ GS & $3.56 \pm 0.63$ & $2.91 \pm 0.63$ & $0.001^{*}$ & $3.80 \pm 0.64$ & $3.23 \pm 0.64$ & $0.001 *$ \\
\hline MSQ IS & $3.81 \pm 0.62$ & $3.14 \pm 0.65$ & $0.001 *$ & $3.96 \pm 0.66$ & $3.51 \pm 0.66$ & $0.001 *$ \\
\hline MSQ ES & $3.18 \pm 0.80$ & $2.57 \pm 0.78$ & $0.001 *$ & $3.57 \pm 0.74$ & $2.80 \pm 0.77$ & $0.001 *$ \\
\hline
\end{tabular}

MBI EE: Maslach Burnout Inventory Emotional Exhaustion, MBI D: Maslach Burnout Inventory Depersonalization, MBI PA: Maslach Burnout Inventory Personal Accomplishment, MSQ GS: Minnesota Satisfaction Questionnaire General Satisfaction, MSQ IS: Minnesota Satisfaction Questionnaire Intrinsic Satisfaction, MSQ ES: Minnesota Satisfaction Questionnaire Extrinsic Satisfaction, Data are expressed as Mean \pm SD, ${ }^{\circledR}$ Mann-Whitney U test *p<0.001

Table 3. Minnesota Satisfaction Questionnaire and Maslach Burnout Inventory values according to gender and opinion that "I'm successful or not". Data are given as Mean \pm SD. ® Mann-Whitney U test

\begin{tabular}{|c|c|c|c|c|c|c|}
\hline & \multicolumn{3}{|l|}{ Gender } & \multicolumn{3}{|l|}{ I'm successful } \\
\hline MBI EE & $1.93 \pm 0.83$ & $1.93 \pm 0.85$ & 0.470 & $1.75 \pm 0.81$ & $2.41 \pm 0.73$ & $0.001 *$ \\
\hline MBI D & $1.34 \pm 0.84$ & $1.12 \pm 0.86$ & $0.047^{*}$ & $1.28 \pm 0.84$ & $1.79 \pm 0.79$ & $0.001 *$ \\
\hline MBI PA & $1.15 \pm 0.68$ & $1.23 \pm 1.16$ & 0.687 & $1.09 \pm 0.67$ & $1.74 \pm 0.98$ & $0.001^{*}$ \\
\hline MSQ IS & $3.63 \pm 0.70$ & $3.66 \pm 0.63$ & 0.889 & $3.69 \pm 0.68$ & $3.13 \pm 0.69$ & $0.001^{*}$ \\
\hline MSQ ES & $3.04 \pm 0.84$ & $2.89 \pm 0.82$ & 0.252 & $3.06 \pm 0.82$ & $2.70 \pm 0.89$ & $0.001^{*}$ \\
\hline
\end{tabular}

MBI EE: Maslach Burnout Inventory Emotional Exhaustion, MBI D: Maslach Burnout Inventory Depersonalization, MBI PA: Maslach Burnout Inventory Personal Accomplishment, MSQ GS: Minnesota Satisfaction Questionnaire General Satisfaction, MSQ IS: Minnesota Satisfaction Questionnaire Intrinsic Satisfaction, MSQ ES: Minnesota Satisfaction Questionnaire Extrinsic Satisfaction, Data are expressed as Mean \pm SD. ${ }^{\circledR}$ Mann-Whitney U test * p<0.001 
Table 4. Minnesota Satisfaction Questionnaire and Maslach Burnout Inventory values according to answers given to the question "If you can return to the past, would you choose general surgery again?" and "Would you consider departure from the work without retirement?"

\begin{tabular}{|c|c|c|c|c|c|c|}
\hline & \multicolumn{3}{|c|}{$\begin{array}{l}\text { If you can return to the past, would you choose general } \\
\text { surgery again? }\end{array}$} & \multicolumn{3}{|c|}{$\begin{array}{l}\text { Would you consider departure from the work without } \\
\text { retirement? }\end{array}$} \\
\hline & Yes $(n=368)$ & No $(n=262)$ & ®p $\mathrm{p}$ & Yes $(n=191)$ & No $(n=439)$ & ${ }^{\circledR p} \mathrm{p}$ \\
\hline MBI EE & $1.48 \pm 0.73$ & $2.29 \pm 0.72$ & $0.001 *$ & $2.33 \pm 0.73$ & $1.59 \pm 0.77$ & $0.001 *$ \\
\hline MBI D & $1.09 \pm 0.78$ & $1.66 \pm 0.84$ & $0.001 *$ & $1.73 \pm 0.81$ & $1.15 \pm 0.81$ & $0.001 *$ \\
\hline MBI PA & $0.99 \pm 0.74$ & $1.38 \pm 0.65$ & $0.001 *$ & $1.44 \pm 0.63$ & $1.03 \pm 0.73$ & $0.001 *$ \\
\hline MSQ GS & $3.61 \pm 0.65$ & $3.08 \pm 0.64$ & $0.001 *$ & $3.01 \pm 0.60$ & $3.56 \pm 0.67$ & $0.001 *$ \\
\hline MSQ IS & $3.86 \pm 0.65$ & $3.32 \pm 0.65$ & $0.001 *$ & $3.25 \pm 0.62$ & $3.80 \pm 0.66$ & $0.001 *$ \\
\hline MSQ ES & $3.24 \pm 0.82$ & $2.72 \pm 0.77$ & $0.001 *$ & $2.65 \pm 0.74$ & $3.19 \pm 0.83$ & $0.001 *$ \\
\hline
\end{tabular}

MBI EE: Maslach Burnout Inventory Emotional Exhaustion, MBI D: Maslach Burnout Inventory Depersonalization, MBI PA: Maslach Burnout Inventory Personal Accomplishment, MSQ GS: Minnesota Satisfaction Questionnaire General Satisfaction, MSQ IS: Minnesota Satisfaction Questionnaire Intrinsic Satisfaction, MSQ ES: Minnesota Satisfaction Questionnaire Extrinsic Satisfaction, Data are given as Mean \pm SD. ${ }^{\circledR}$ MannWhitney U test * $\mathrm{p}<0.001$

Table 5. Minnesota Satisfaction Questionnaire and Maslach Burnout Inventory values according to the academic title of participants

\begin{tabular}{|c|c|c|c|c|c|c|c|}
\hline Groups & & MBI EE & MBI D & MBI PA & MSQ GS & MSQ IS & MSQ ES \\
\hline Group 2 & $\begin{array}{l}\text { Associate professor } \\
(\mathrm{n}=66)\end{array}$ & $1.58 \pm 0.79$ & $1.13 \pm 0.82$ & $0.98 \pm 0.61$ & $3.52 \pm 0.77$ & $3.76 \pm 0.80$ & $3.16 \pm 0.87$ \\
\hline Group 3 & $\begin{array}{l}\text { Assistant Professor } \\
(\mathrm{n}=41)\end{array}$ & $1.57 \pm 0.70$ & $1.18 \pm 0.68$ & $1.05 \pm 0.6$ & $3.45 \pm 0.513$ & $3.75 \pm 0.51$ & $3.00 \pm 0.74$ \\
\hline \multirow{4}{*}{$\mathrm{p}^{\circledR}$} & $\begin{array}{l}\text { Group } 1 \\
\text { Group } 2\end{array}$ & $0.029 *$ & $0.031 *$ & 0.203 & $0.045^{*}$ & 0.089 & $0.030 *$ \\
\hline & $\begin{array}{l}\text { Group } 2 \\
\text { Group } 3\end{array}$ & 0.867 & 0.530 & 0.478 & 0.309 & 0.432 & 0.231 \\
\hline & $\begin{array}{l}\text { Group } 2 \\
\text { Group } 4\end{array}$ & $0.001^{*}$ & $0.008^{*}$ & $0.007^{*}$ & $0.007^{*}$ & $0.004 *$ & $0.025^{*}$ \\
\hline & $\begin{array}{l}\text { Group3 } \\
\text { Group } 4\end{array}$ & $0.005^{*}$ & 0.077 & 0.164 & 0.127 & 0.054 & 0.645 \\
\hline
\end{tabular}

MBI EE: Maslach Burnout Inventory Emotional Exhaustion, MBI D: Maslach Burnout Inventory Depersonalization, MBI PA: Maslach Burnout Inventory Personal Accomplishment, MSQ GS: Minnesota Satisfaction Questionnaire General Satisfaction. MSQ IS: Minnesota Satisfaction Questionnaire Intrinsic Satisfaction, MSQ ES: Minnesota Satisfaction Questionnaire Extrinsic Satisfaction, Data are given as Mean \pm SD, ㄹ MannWhitney U test * $\mathrm{p}<0.05$ 
Table 6. Minnesota Satisfaction Questionnaire and Maslach Burnout Inventory values according to the age of the participants

\begin{tabular}{|c|c|c|c|c|c|c|c|}
\hline Groups & & MBI EE & MBI D & MBI PA & MSQ GS & MSQ IS & MSQ ES \\
\hline Group 1 & $30-40(n=303)$ & $1.96 \pm 0.813$ & $1.45 \pm 0.84$ & $1.16 \pm 0.65$ & $3.35 \pm 0.62$ & $3.61 \pm 0.60$ & $2.95 \pm 0.80$ \\
\hline Group 2 & $41-50(n=219)$ & $1.80 \pm 0.81$ & $1.30 \pm 0.83$ & $1.27 \pm 0.82$ & $3.32 \pm 0.75$ & $3.54 \pm 0.77$ & $2.99 \pm 0.85$ \\
\hline Group 3 & $51-60(n=93)$ & $1.45 \pm 0.79$ & $1.03 \pm 0.80$ & $0.90 \pm 0.68$ & $3.66 \pm 0.71$ & $3.88 \pm 0.67$ & $3.32 \pm 0.87$ \\
\hline Group 4 & $\geq 61(n=15)$ & $1.33 \pm 0.84$ & $0.89 \pm 0.91$ & $0.90 \pm 0.87$ & $3.64 \pm 0.86$ & $3.96 \pm 1.00$ & $3.17 \pm 0.81$ \\
\hline \multirow{6}{*}{$\mathrm{p}^{\circledR}$} & $\begin{array}{l}\text { Group } 1 \\
\text { Group } 2\end{array}$ & $0.020^{*}$ & 0.056 & 0.136 & 0.765 & 0.498 & 0.583 \\
\hline & $\begin{array}{l}\text { Group } 1 \\
\text { Group } 3\end{array}$ & $0.001 *$ & $0.001^{*}$ & $0.001^{*}$ & $0.001 *$ & $0.001^{*}$ & $0.001 *$ \\
\hline & $\begin{array}{l}\text { Groupl } \\
\text { Group } 4\end{array}$ & $0.002 *$ & $0.005^{*}$ & $0.042 *$ & 0.055 & $0.016^{*}$ & 0.252 \\
\hline & $\begin{array}{l}\text { Group } 2 \\
\text { Group } 3\end{array}$ & $0.001 *$ & $0.004 *$ & $0.001^{*}$ & $0.001 *$ & $0.001^{*}$ & $0.003 *$ \\
\hline & $\begin{array}{l}\text { Group } 2 \\
\text { Group } 4\end{array}$ & $0.014^{*}$ & $0.031^{*}$ & $0.024 *$ & 0.068 & $0.018^{*}$ & 0.367 \\
\hline & $\begin{array}{l}\text { Group3 } \\
\text { Group } 4\end{array}$ & 0.393 & 0.367 & 0.692 & 0.810 & 0.235 & 0.560 \\
\hline
\end{tabular}

Data are given as Mean \pm SD. ㅅ Mann-Whitney U test * $\mathrm{p}<0.05$, SD: Standard deviation

\section{Discussion}

General surgeons work intensely over a long period of time and make important personal sacrifices for their jobs. Some of these sacrifices include working for long hours, working at nights and weekends, complying with multiple time constraints, and refraining from complaining or allowing their emotions or personal problems affect their work. These sacrifices are indicative of a dedicated professional who should be appreciated and rewarded. However, there is a fine line between dedication and over-work. When general surgeons are over-worked, they can experience adverse effects on their own health and on the health of their patients. Studies have shown that a significant number of surgeons experience burnout or stress, which may cause negative consequences on the surgeons, including their families, colleagues, and/or patients. ${ }^{10}$

It is known that burnout is especially common in surgical specialties. In their large-scale study, Shanafelt et al. ${ }^{15}$ reported that $40 \%$ of surgeons met the criteria for high burnout and that $31.7 \%$ of the participants had high EE, $26 \%$ had high DP, and $12.8 \%$ reported low PA. In another study including 521 general and orthopedic surgeons, 32\% of the respondents had high EE, 13\% had high DP, and $4 \%$ had low PA. ${ }^{16}$ Kuerer et al. ${ }^{17}$ reported that surgical oncologists had a burnout prevalence of $28 \%$ according to MBI criteria and 30\% depression rate according to the Primary Care Evaluation of Mental Disorders (PRIME-MD) scale. Kuerer et al. ${ }^{17}$ results are in accordance with those of Balch et al. ${ }^{18}$ who surveyed 407 surgical oncologists, 36.1\% of which reported burnout. Studies in most of the surgical sub-branches have reported overall burnout rates exceeding $30 \% .^{15,18,19,20}$ It is pertinent to note that the prevalence of burnout among surgeons increases over time. In the recent Medscape Physician Lifestyle report, the burnout rate of general surgeons was near the top of the list at $50 \% .{ }^{21}$ In the study by Shanafelt et al..$^{22}$, the prevalence of burnout among doctors increased from 46\% to 54\% between 2011 and 2014 and the satisfaction with work-life balance decreased from $48 \%$ to $41 \%$. The same study also reported that the prevalence of burnout among surgeons was $40 \%$ in 2009 , which increased to $53 \%$ in $2015 .^{15,22}$

In addition to the increasing prevalence of burnout across the world, increased hospital admissions caused by Turkish health care reforms caused the increase of physician workload, leading to a further deterioration in the patientphysician relationship, which has been reported in several studies. ${ }^{23,24}$ However, to the best of our knowledge, there are no studies on general surgeons in Turkey in this regard. The current study is the first to investigate burnout in general surgeons in Turkey. In this study, $74.4 \%$ of the participants were emotionally satisfied, but $70.8 \%$ were not financially satisfied. The scores of those that were emotionally dissatisfied were significantly higher on the MBI and lower on the MSQ $(p<0.05)$. These results indicate that these 
Table 7. Minnesota Satisfaction Questionnaire and Maslach Burnout Inventory values according to the work experience of the participants

\begin{tabular}{|c|c|c|c|c|c|c|c|}
\hline Groups & & MBI EE & MBI D & MBI PA & MSQ GS & MSQ IS & MSQ ES \\
\hline Group 1 & $6-10$ year $(n=192)$ & $1.98 \pm 0.83$ & $1.50 \pm 0.86$ & $1.22 \pm 0.63$ & $3.33 \pm 0.61$ & $3.59 \pm 0.61$ & $2.95 \pm 0.76$ \\
\hline Group 2 & $11-15$ year $(n=165)$ & $1.86 \pm 0.80$ & $1.35 \pm 0.85$ & $1.11 \pm 0.68$ & $3.39 \pm 0.69$ & $3.61 \pm 0.67$ & $3.04 \pm 0.68$ \\
\hline Group 3 & $16-20$ year $(n=97)$ & $1.94 \pm 0.74$ & $1.44 \pm 0.79$ & $1.42 \pm 0.93$ & $3.17 \pm 0.71$ & $3.40 \pm 0.78$ & $2.83 \pm 0.79$ \\
\hline Group 4 & $21-25$ year $(n=84)$ & $1.56 \pm 0.81$ & $1.04 \pm 0.71$ & $1.12 \pm 0.75$ & $3.51 \pm 0.67$ & $3.78 \pm 0.64$ & $3.10 \pm 0.87$ \\
\hline Group 5 & $\geq 26(n=92)$ & $1.48 \pm 0.82$ & $1.05 \pm 0.87$ & $0.84 \pm 0.65$ & $3.65 \pm 0.79$ & $3.89 \pm 0.78$ & $3.29 \pm 0.92$ \\
\hline \multirow{10}{*}{$\mathrm{p}^{\circledR}$} & $\begin{array}{l}\text { Group } 1 \\
\text { Group } 2\end{array}$ & 0.132 & 0.118 & 0.058 & 0.382 & 0.454 & 0.282 \\
\hline & $\begin{array}{l}\text { Group } 1 \\
\text { Group } 3\end{array}$ & 0.625 & 0.741 & 0.074 & 0.068 & 0.106 & 0.257 \\
\hline & $\begin{array}{l}\text { Group } 1 \\
\text { Group } 4\end{array}$ & $0.001^{*}$ & $0.001 *$ & 0.160 & 0.055 & $0.016^{*}$ & 0.191 \\
\hline & $\begin{array}{l}\text { Group } 1 \\
\text { Group } 5\end{array}$ & $0.001^{*}$ & $0.001^{*}$ & $0.001 *$ & $0.001^{*}$ & $0.001 *$ & $0.001 *$ \\
\hline & $\begin{array}{l}\text { Group } 2 \\
\text { Group } 3\end{array}$ & 0.388 & 0.333 & $0.002 *$ & $0.019 *$ & $0.030 *$ & 0.056 \\
\hline & $\begin{array}{l}\text { Group } 2 \\
\text { Group } 4\end{array}$ & $0.008^{*}$ & $0.006^{*}$ & 0.950 & 0.272 & 0.083 & 0.747 \\
\hline & $\begin{array}{l}\text { Group } 2 \\
\text { Group } 5\end{array}$ & $0.001^{*}$ & $0.002 *$ & $0.002 *$ & $0.003 *$ & $0.001 *$ & $0.027 *$ \\
\hline & $\begin{array}{l}\text { Group } 3 \\
\text { Group } 4\end{array}$ & $0.021 *$ & $0.021 *$ & $0.012 *$ & $0.003 *$ & $0.001^{*}$ & $0.042 *$ \\
\hline & $\begin{array}{l}\text { Group } 3 \\
\text { Group } 5\end{array}$ & $0.001^{*}$ & $0.001 *$ & $0.001 *$ & $0.001 *$ & $0.001 *$ & $0.001 *$ \\
\hline & $\begin{array}{l}\text { Group } 4 \\
\text { Group } 5\end{array}$ & 0.409 & 0.562 & $0.013 *$ & 0.083 & 0.161 & 0.115 \\
\hline
\end{tabular}

MBI EE: Maslach Burnout Inventory Emotional Exhaustion, MBI D: Maslach Burnout Inventory Depersonalization, MBI PA: Maslach Burnout Inventory Personal Accomplishment, MSQ GS: Minnesota Satisfaction Questionnaire General Satisfaction, MSQ IS: Minnesota Satisfaction Questionnaire Intrinsic Satisfaction, MSQ ES: Minnesota Satisfaction Questionnaire Extrinsic Satisfaction, Data are given as Mean \pm SD. ${ }^{\circledR}$ MannWhitney U test * $\mathrm{p}<0.05$

people have greater EE and DP, decreased levels of PA, and less IS, ES, and GS.

Many studies have investigated the factors associated with burnout among surgeons. ${ }^{17,25,26,27}$ The most common factor reported to contribute to burnout is difficulty with work-life balance. ${ }^{11}$ Among the risk factors for difficulty with worklife balance are age, marital status, having children, working nights and long hours, gender, lack of administrative support, and legal problems. ${ }^{11,13}$ When sociodemographic variables were examined in the current literature, it was found that MBI DP scores of the female general surgeons were lower than those of the male general surgeons. In this study, the female gender was a factor in reducing DP. There are contradictory studies reporting that intense work stress and burnout are more common among males or more common in females; however, some studies have reported no difference in terms of gender. ${ }^{11,13,28}$

Job satisfaction is the joy that employees feel when they perform their job. Job satisfaction is correlated with the degree of an employee's pleasure from work. The current study revealed that, as work experience increases, burnout syndrome diminishes and job satisfaction increases. These results indicate that it becomes easier to deal with burnout syndrome as work experience and age increases. It has been reported that burnout is more common in young and inexperienced employees compared to senior employees. ${ }^{28}$ The reason for this may be that young employees have not yet developed a sense of dedication to their profession and 
because the feelings of "being in control" of the job have not yet been developed. In addition, those who are relatively new in their profession may have a higher level of EE. This is because 1) they are not able to feel autonomous on the hierarchical level, 2) the authorities have more control over them, and 3) they are required to perform more routine practices. ${ }^{11,16}$

When the effects of academic title on burnout syndrome and job satisfaction were examined, it was found that burnout decreases and job satisfaction increases with increasing academic title. Those with higher academic titles often have reduced workload and less hierarchical oppression, greater work flexibility, and are often specialized in specific areas within general surgery, which may influence burnout and job satisfaction.

Material and emotional job satisfaction reduces burnout syndrome and increases pleasure from work. ${ }^{6,7}$ According to data generated in this study, EE, DP, and decrease in PA were lower, while IS, ES, and GS were higher in general surgeons who were satisfied both financially and emotionally.

Data generated from this study indicate that the study participants did not receive appropriate compensation (both emotionally and financially) for their 11 years of education, hard working conditions, and intense stress, which are often required to become a general surgeon. Results from this study show that these feelings are present in those who would not choose to become a general surgeon again and in those who would consider departure from the work without retirement. For these groups, MBI subgroup scores were higher, while MSQ subgroup scores were lower. The reason for these scores was related to pessimism, tiredness, and dissatisfaction in both material and emotional terms about the profession. A study involving 582 general surgeons who graduated from the University of Michigan demonstrated a strong association between burnout and desire for early retirement. ${ }^{29}$ Another study including 501 colorectal and vascular surgeons in the UK reported that $32 \%$ had a higher burnout rate according to, at least, 1 subgroup score of the MBI and those who planned for an early retirement had a higher burnout rate. ${ }^{30}$

\section{Study Limitations}

Participants who found themselves successful in this study had lower scores in the MBI subgroups and higher scores in the MSQ subgroups. EE, DP, and decrease in PA were lower and GS, ES, and IS were higher in general surgeons who described themselves as being successful. In this study, we did not determine whether the general surgeons found themselves unsuccessful. Therefore, we believe that more detailed studies should be conducted with groups of general surgeons who find themselves unsuccessful and desire early retirement.

\section{Conclusion}

The results of this study indicate that EE, PA, and DP decreased and that GS, ES, and IS increased among those who found themselves successful, had more work experience, and had increased academic titles. Considering the working conditions of general surgeons, the high rate of burnout syndrome can cause serious problems in terms of physician and patient health. To solve this problem, it is necessary to first recognize and discuss the phenomenon of burnout. Outside of surgery, a variety of programs should be designed and made available to teach physicians how to respond to the stress they experience on a daily basis, thereby promoting their well-being and preventing burnout.

\section{Ethics}

Ethics Committee Approval: Trakya University Faculty of Medicine Scientific Research Ethics Committee (no: 04/07, date: 27.02 .2016$)$

Peer-review: Externally and internally peer reviwed.

\section{Authorship Contributions}

Surgical and Medical Practices: E.Y., T.S., Concept: E.Y., Design: E.Y., T.S., Data Collection or Processing: E.Y., İ.E.C., Analysis or Interpretation: E.Y., İ.E.C., Literature Search: E.Y., Writing: E.Y., İ.E.C.,

Conflict of Interest: No conflict of interest was declared by the authors.

Financial Disclosure: The authors declared that this study received no financial support.

\section{References}

1. Freudenberger HJ. Staff burn-out. J Soc Issue 1974;30:159.

2. Maslach C, Pines A. The burn-out syndrome in the day care setting. Child Care Q 1977;3:6100-6113.

3. Keel P. Psychische belastungen dursch die Arbeit, Burnout syndrom. Praeventumed. 1993;2:131-132.

4. Jackson SE, Schwab RL, Schuler RS. Toward an understanding of the burnout phenemeo. J App Psychol 1986;11:615-627.

5. Balch CM, Shanafelt T. Combating stress and burnout in surgical practice: a review. Adv Surg 2010;44:29-47.

6. Maslach C, Jackson SE. The measurement of experienced burnout. J Occup Behav 1981;2:99-113.

7. Nagy S, Davis LG. Burnout: a comparative analysis of personality and environmental variables. Psychol Rep 1985;57:1319-1326.

8. Beemsterboer J, Baum BH. "Burnout": definitions and health care management. Soc Work Health Care 1984;10:97-109.

9. Gorgulu O, Akilli A. The determination of the levels of burnout syndrome, organizational commitment, and job satisfaction of the health workers. Niger J Clin Pract 2017;20:48-56.

10. Rick J, Briner RB. Psychosocial risk assessment: problems and prospects. Occup Med (Lond) 2000;50:310-314.

11. Dimou FM, Eckelbarger D, Riall TS. Surgeon burnout: a systematic review. J Am Coll Surg 2016;222:1230-1239. 
12. Elmore LC, Jeffe DB, Jin L, Awad MM, Turnbull IR. National Survey of Burnout among US General Surgery Residents. J Am Coll Surg 2016;223:440-451.

13. Pulcrano M, Evans SR, Sosin M. Quality of life and burnout rates across surgical specialties: a systematic review. JAMA Surg 2016;151:970-978.

14. Ergin C. Doktor ve hemşirelerde tükenmişlik ve Maslach tükenmişlik ölçeğinin uyarlanması. VII Ulusal psikoloji kongresi bilimsel çalışmaları. 1992;22:25

15. Shanafelt TD, Balch CM, Bechamps GJ, Russell T, Dyrbye L, Satele D, Collicott P, Novotny PJ, Sloan J, Freischlag JA. Burnout and career satisfaction among American surgeons. Ann Surg 2009;250:463-471.

16. Campbell DA, Jr., Sonnad SS, Eckhauser FE, Campbell KK, Greenfield LJ. Burnout among American surgeons. Surgery 2001;130:696-702; discussion 702-695.

17. Kuerer HM, Eberlein TJ, Pollock RE, Huschka M, Baile WF, Morrow M, Michelassi F, Singletary SE, Novotny P, Sloan J, Shanafelt TD. Career satisfaction, practice patterns and burnout among surgical oncologists: report on the quality of life of members of the Society of Surgical Oncology. Ann Surg Oncol 2007;14:3043-3053.

18. Balch CM, Shanafelt TD, Sloan JA, Satele DV, Freischlag JA. Distress and career satisfaction among 14 surgical specialties, comparing academic and private practice settings. Ann Surg 2011;254:558-568.

19. Contag SP, Golub JS, Teknos TN, Nussenbaum B, Stack BC Jr, Arnold DJ, Johns MM 3rd. Professional burnout among microvascular and reconstructive free-flap head and neck surgeons in the United States. Arch Otolaryngol Head Neck Surg 2010;136:950-956

20. Dyrbye LN, Shanafelt TD, Balch CM, Satele D, Sloan J, Freischlag J. Relationship between work-home conflicts and burnout among American surgeons: a comparison by sex. Arch Surg 2011;146:211-217.

21. Peckham C. Medscape Physician Lifestyle Report 2015; 2015. Available from: http://www.medscape.com/features/slideshow/lifestyle/2015/public/ overview.
22. Shanafelt TD, Hasan O, Dyrbye LN, Sinsky C, Satele D, Sloan J, West CP. Changes in burnout and satisfaction with work-life balance in physicians and the General US Working Population between 2011 and 2014. Mayo Clin Proc 2015;90:1600-1613.

23. Atik M, Ucan ES, Ellidokuz H, Alptekin K. Burnout in chest physicians after health care reforms: a cross-sectional study in Turkey. Turk Thorac J 2019;20:18-24

24. Elay G, Bahar I, Demirkiran H, Oksuz H. Severe burnout among critical care workers in Turkey. Saudi Med J 2019;40:943-948.

25. Gifford E, Galante J, Kaji AH, Nguyen V, Nelson MT, Sidwell RA, Hartranft T, Jarman B, Melcher M, Reeves M, Reid C, Jacobsen GR, Thompson J, Are C, Smith B, Arnell T, Hines OJ, de Virgilio C. Factors associated with general surgery residents' desire to leave residency programs: a multiinstitutional study. JAMA Surg 2014;149:948-953.

26. Guest RS, Baser R, Li Y, Scardino PT, Brown AE, Kissane DW. Cancer surgeons' distress and well-being, I: the tension between a culture of productivity and the need for self-care. Ann Surg Oncol 2011;18:12291235.

27. Sargent MC, Sotile W, Sotile MO, Rubash H, Barrack RL. Stress and coping among orthopaedic surgery residents and faculty. J Bone Joint Surg Am 2004;86:1579-1586.

28. Olkinuora M, Asp S, Juntunen J, Kauttu K, Strid L, Aarimaa M. Stress symptoms, burnout and suicidal thoughts in Finnish physicians. Soc Psychiatry Psychiatr Epidemiol 1990;25: 81-86.

29. Sharma A, Sharp DM, Walker LG, Monson JR. Stress and burnout in colorectal and vascular surgical consultants working in the UK National Health Service. Psychooncology 2008;17:570-576.

30. Sharma A, Sharp DM, Walker LG, Monson JR. Stress and burnout among colorectal surgeons and colorectal nurse specialists working in the National Health Service. Colorectal Dis 2008;10:397-406. 